\title{
УПРАВЛІННЯ ПРОМИСЛОВИМИ ВІДХОДАМИ У МІСТІ: ІНСТИТУЦІї, ІНВЕСТИЦІї, ІННОВАЦІї
}

\section{MANAGEMENT OF INDUSTRIAL WASTE IN THE CITY: INSTITUTIONS, INVESTMENTS, INNOVATIONS}

\author{
Мельникова Марина Віталіївна \\ доктор економічних наук, доцент, \\ Інститут економіки промисловості Національної академії наук України \\ ORCID: https://orcid.org/0000-0002-5342-622X \\ Шкригун Валерія Леонідівна \\ кандидат економічних наук, \\ Інститут економіки промисловості Національної академії наук України \\ ORCID: https://orcid.org/0000-0003-3185-5274 \\ Хазанова Наталія Миколаївна \\ Інститут економіки промисловості Національної академії наук України \\ ORCID: https://orcid.org/0000-0002-1184-6074
}

\author{
Melnykova Maryna, Shkrygun Valeriia, Khazanova Nataliia \\ Institute of industrial economics \\ of the National Academy of Sciences of Ukraine
}

\begin{abstract}
У статті досліджено питання управління промисловими відходами міста в інституційному, інвестиційному та інноваційному аспекті. Охарактеризовано процес управління промисловими відходами та його основні учасники. Представлено шляхи вдосконалення інституційного середовища та підвищення інвестиційної привабливості сорери управління промисловими відходами міста, а також підкреслено соціальну значущість впровадження інновацій у переробку промислових відходів. Запропоновано методичний підхід до організації кластера з переробки промислових відходів на прикладі доменних шлаків. Формування інституційного середовища в середині кластера, забезпечення привабливості для інвесторів та організація взаємодії між державою, наукою та бізнесом на кшталт «потрійна спіраль» дозволяє реалізовувати проекти 3 переробки промислових відходів для вирішення економічних, екологічних та соціальних завдань сталого розвитку міста.

Ключові слова: місто, промислові відходи, управління, інституції, інвестиції, інновації.
\end{abstract}

В статье исследованы вопросы управления промышленными отходами города в институциональном, инвестиционном и инновационном аспекте. Охарактеризованы процесс управления промышленными отходами и их основные участники. Представлены пути совершенствования институциональной среды и повышения инвестиционной привлекательности ссреры управления промышленными отходами города, а также подчеркнута социальная значимость внедрения инноваций в переработку промышленных отходов. Предложен методический подход к организации кластера по переработке промышленных отходов на примере доменных шлаков. Формирование институциональной среды внутри кластера, обеспечение привлекательности для инвесторов и организация взаимодействия между государством, наукой и бизнесом - «тройная спираль» позволяет реализовывать проекты по переработке промышленных отходов для решения экономических, экологических и социальных задач устойчивого развития города.

Ключевые слова: город, промышленные отходы, управление, институции, инвестиции, инновации.

The article examines the issues of industrial waste management of the city. The relevance of the study is determined by the negative impact of industrial waste on the environment, the deterioration of the ecological situation and the creation of uncomfortable conditions for the life of the population. The methods of cognition were used for the study: analysis and synthesis, comparison, analogy, logical generalization, and a systematic approach. The purpose of the study is to develop proposals for taking into account institutional, investment and innovative aspects in the formation of solutions for the management of industrial waste in the city. The process of industrial waste management in the city is characterized from the functional and situational points of view. The main participants in the process of 
industrial waste management in the city have been identified. The assessment of the state of the institutional environment in the city is carried out and the directions of its improvement for the management of industrial waste are presented. The investment support of industrial waste management projects has been analyzed and developed to increase their attractiveness for investors. The necessity of including an innovative component in the process of industrial waste management is substantiated and its social significance is emphasized. A methodological approach to the formation of a cluster for the processing of industrial waste is proposed using the example of blast-furnace slag. Within the framework of the cluster, interaction is carried out according to the type of "triple helix" between the state, science and business. At the same time, an institutional environment is created within the cluster, which ensures cooperation between the participants in the process of production, processing and use of industrial waste. Investment attractiveness is achieved through transparency, information accessibility, as well as the provision of benefits and preferences to investors. Within the framework of the cluster, its participants make and implement design solutions for the processing of industrial waste. This creates the prerequisites for solving the problems of sustainable development of the city, including saving local resources, maintaining ecological balance, improving the living conditions of the population. Further research is required on the organization of public participation in the processes of industrial waste management within the cluster.

Keywords: city, industrial waste, management, institutions, investments, innovations.

Постановка проблеми. Звертання уваги до дослідження питань управління промисловими відходами міста, пов'язана з вирішенням завдань сталого розвитку щодо раціонального використання місцевих ресурсів, підтримки екологічної безпеки та створення комсоортних умов життя населення, які задекларовано у відповідних документах на державному, регіональному та міському рівні, зокрема Державною стратегією регіонального розвитку на 2021-2027 роки, яку прийнято Постановою Кабінету Міністрів від 5 серпня 2020 р. № 695, регіональних стратегіях та міських програмах економічного та соціального розвитку, з одного боку, та незадовільним екологічним становищем, яке викликано значним забрудненням міської території відвалами промислових відходів, про що йдеться зокрема в Концепції реалізації державної політики у сфрері промислового забруднення, яку прийнято Розпорядженням Кабінету Міністрів України від 27 грудня 2019 р. № 1422-p.

Аналіз останніх досліджень і публікацій. Останнім часом серед вчених та практиків проявляється жвавий інтерес до проблеми управління промисловими відходами. Серед вітчизняних досліджень слід зазначити монографію І.А. Колодійчука [1], а також наукові роботи О. Мініної, Н. Шадура-Никипореця [2], Н.М. Потапової [3], Р.О. Тімченка, Д.А. Крішка та Є.В. Тітуніна [4]. Що стосується зарубіжних дослідників, то особливої уваги заслуговують монограсрія А.П. Бартолетто [5], стаття P.Е. Маршалла та К. Фарахбарша [6], дослідження Ю.В. Никуличева [7] та С.С. Лупина [8]. Спираючись на представлені дослідження та власний досвід розглянемо особливості інституцій, інвестицій та інновацій в процесі управління промисловими відходами у місті.
Формулювання цілей статті. Метою дослідження $є$ розробка пропозицій щодо урахування інституційних, інвестиційних, інноваційних аспектів з фрормування рішень щодо управління промисловими відходами у місті.

Виклад основного матеріалу дослідження. Згідно 3 Директивою 2008/98/ЄС впровадження «зеленого курсу» в енергетиці передбачає не тільки дбайливе відношення до мінеральних ресурсів, але й захист довкілля від негативного впливу техногенних фракторів, які генеруються під час діяльності підприємств гірничо-металургійного комплексу, що займає найбільш вагоме місто в структурі економіки України. За даними Державної служби статистики України у 2019 р. три регіони України надали найбільшу частку відходів I-IV класів небезпеки (Дніпропетровська область - 57,1\%, Полтавська - 22,1\%, Кіровоградська - 8,5\%, Донецька - 5,8\%, Запорізька - 1,2\%) [9]. У зазначених регіонах розташовано міста, які протягом останніх п'яти років за даними спостережень Центральної геофрізичної обсерваторії (ЦДО) ім. Бориса Срезневського займають перші позиції за індексом забруднення території - Дніпро, Запоріжжя, Кам'янське, Кривий Ріг, Маріуполь. I хоча у зазначених містах органами державного управління та місцевого самоврядування приймаються активні природоохоронні заходи, приймаються та реалізуються Регіональні програми поводження $з$ промисловими відходами, та підприємствами ГМК сплачуються значні суми екологічних податків, та взято курс на впровадження елементів реціклінгу виробництва та переходу до «зеленої» металургії, відвали відходів, особливо доменних шлаків, продовжують зростати. Як зазначає О. Титамир, в Україні «щорічно нагромаджується в серед- 
ньому близько 450 млн т (у тому числі понад 250 млн т вугільних та понад 160 металургійних шлаків), що у 40 разів більше за тверді побутові відходи. Від 4 до 7\% території України займають відходи промислових підприємств. А площа українських земель під шламосховищами, териконами та відвалами становить близько 260 тис. га» [10]. Це викликає необхідність прийняття відповідних рішень 3 управління відходами металургійного виробництва $з$ урахуванням дії інституційних, інвестиційних та інноваційних чинників та умов.

Під управлінням відходами, як визначено в проекті Закону України «Про управління відходами» № 2207-1-д від 03.06.2020 р., розуміється «збирання, перевезення, відновлення (у тому числі сортування) та видалення відходів, включаючи нагляд за такими операціями та подальший догляд за об'єктами видалення відходів». Спираючись на представлене визначення можна стверджувати, що процес управління промисловими відходами міста являє собою обґрунтування, прийняття та реалізацію фрункціональних та ситуаційних рішень. Функціональні рішення спрямовані на планування, координацію, срінансування, контроль діяльності зі збирання, перевезення, переробки, а також видалення промислових відходів. Ситуаційні рішення пов'язані з подоланням форс-мажорних обставин або впровадженням новітніх технологій та організаційних змін, спрямованих на поглиблення переробки промислових відходів та раціональне використання вторинних ресурсів. Впровадження новітніх технологій пов'язано 3 модернізацією виробничих потужностей та підготовкою кадрів підприємств, що займаються збиранням, перевезенням, переробкою та видаленням промислових відходів. Організаційні зміни передбачають спеціалізацію підприємств 3 переробки промислових відходів та їх кооперацію з виробниками промислових відходів та споживачами продуктів переробки відходів. Управління промисловими відходами на території міста має особливості, обумовлені наявністю підприємств містоутворюючого, містообслуговуючого та містобудівного комплексів, які пов'язані між собою не тільки територією, але й господарськими зв'язками. Територіальна громада, інтереси якої представляють органи місцевого самоврядування, має власні повноваження у вирішенні питань міського значення в контексті забезпечення сталого розвитку території, включаючи поводження 3 промисловими та побутовими відходами.
Раціональне використання матеріальних ресурсів досягається шляхом максимальної ефрективності їх використання на підприємстві за рівня розвитку техніки і технології з одночасним зниженням техногенного впливу на навколишнє середовище. Ресурсозбереження має на меті досягнення конкретних цілей, основною з яких є підвищення соціо-еколого-економічної ефрективності виробництва при зниженні його ресурсоємності. При цьому використовуються два способи організації переробки промислових відходів - централізований збір та транспортування спеціалізованими підприємствами відходів першого-третього класу та децентралізований - для відходів четвертого класу, переробка яких здійснюється неспеціалізованими підприємствами на місцях, зокрема підприємствами промисловості будівельних матеріалів.

У межах інституційного середовища здійснюється взаємозв'язок між підприємствами містоутворюючого, містообслуговуючого та містобудівного комплексів 3 питань переробки вторинних ресурсів в системі управління промисловими відходами міста. При цьому використовуються ринкові та неринкові механізми, створюються формальні та несрормальні інститути та інституції, встановлюються норми, правила та порядки. Найважливішим фрормальним інститутом при цьому виступає нормативно-правова база, яка забезпечує координацію діяльності підприємств, що господарюють у сорері управління промисловими відходами міста та здійснюють переробку вторинних ресурсів, що дозволяє забезпечити підтримку системи контрактації та контролювати дотримання умов екологічної безпеки. Тому вкрай важливим в даний час постає прийняття Закону України «Про управління відходами», що знаходиться на розгляді у Верховній Раді України. Не менш важливим завданням переробки вторинних ресурсів у системі управління промисловими відходами міста $€$ підвищення інвестиційної привабливості проектів та стимулювання впровадження інноваційних енерго- та ресурсозберігаючих технологій. При цьому доцільно задіяти різні методи та інструменти. Зокрема це стосується перерозподілу сум екологічного податку між державним та місцевими бюджетами, надання пільгових режимів підприємцям, що інвестують кошти у розвиток сорери переробки промислових відходів, тарифне регулювання перевезень промислових відходів як вторинних ресурсів, використання механізмів державно-приватного партнерства 
(ДПП). Для залучення приватних інвестицій у реалізацію проектів 3 переробки промислових відходів на основі ДПП необхідно внесення змін у законодавче забезпечення щодо визначення конкретних фрорм партнерства, окреслення процедур обґрунтування та прийняття узгоджених рішень партнерами, визначення умов спільного використання ними різних видів ресурсів та можливостей розподілу результатів між учасниками реалізації проекту. Крім того доцільно надання пільг приватним інвесторам на етапі реалізації готової продукції в рамках проекту ДПП, а при розподілі ризиків держава повинна гарантувати захист приватних інвестицій.

При впровадженні інновацій у сореру управління промисловими відходами міста слід керуватися тим, що вони повинні бути спрямовані на зниження обсягів та площ, які займають відвали, та підтримку екологічної безпеки. Особливої уваги при цьому заслуговують відвали відходів збагачувального та металургійного виробництва, зокрема відвали металургійних шлаків, які можуть бути перероблені та використані підприємствами містобудівного та містообслуговуючого комплексу, що у свою чергу відповідає принципам циркулярності, сталого розвитку та промислової екології.

3 позиції «зеленої металургії» при управлінні відходами необхідно забезпечення не тільки впровадження безвідходного виробництва, але й відновлення екосистемних функкцій відповідних територій, зайнятих відвалами доменних та сталеплавильних шлаків та шламів. Ці заходи мають як еколого-економічне, так і соціальне значення, особливо у великих містах та агломераціях, до яких відносяться Дніпро, Запоріжжя, Кам`янське, Кривий Ріг, Маріуполь. Еколого-економічне значення заходів 3 рекультивації територій регулюється відповідним законодавством, потребує створення інституційних умов та забезпечення інвестиційної привабливості, а соціальне значення обумовлено інноваційними підходами та розширенням участі громадськості. Тому при прийнятті рішень щодо впровадження інновацій перевага повинна бути віддана соціальної спрямованості, що дозволить оцінити не тільки ії̈ економічне, але й екосистемне значення, яке в контексті управління промисловими відходами передбачає зменшення навантаження на довкілля, забезпечення раціонального землекористування як невід'ємної складової збереження природної геосистеми міста. Управління промисловими відходами у місті, яке засноване на збереженні екосистемних функцій відповідної території на підставі впровадження інновацій та залучення інвестицій доцільно реалізовувати в межах так званої «потрійної спіралі» [11; 12]. «Потрійна спіраль» $€$ класичною моделлю взаємодії держави (влади), бізнесу (виробництва), освіти та науки, до якої в даний час пропонується додати такий елемент як «суспільство (громадськість)», що важливо для забезпечення прозорості фрункціонування сорери управління промисловими відходами у місті. Організація процесу управління відходами у місті на підставі використання моделі «потрійна спіраль» може бути реалізована шляхом створення кластеру. Для забезпечення фуункціонування всіх ланок кластеру - «влада-бізнес-наука-суспільство (громадськість)» доцільно створення відповідної інфрраструктури, встановлення коопераційних зв'язків та відносини між учасниками, що надасть можливості реалізації спільних інвестиційних проектів для впровадження інновацій, які розробляються установами науки та освіти. Основою функціонування кластеру $€$ належне інституціональне середовище, яке регламентує відносини між учасниками кластеру та дозволяє забезпечити узгоджене планування між виробниками промислових відходів (вторинних ресурсів), переробниками вторинних ресурсів та споживачами продукції, яка виробляється з вторинних ресурсів.

Як свідчить вітчизняна практика використання кластерного підходу для переробки промислових відходів, в Кривому Розі було запропоновано створення будівельного кластеру [13; 14]. Авторами проекту відповідно до структури економіки міста та суміжних територій обрано напрямки розвитку; оцінено концентрацію галузі та групи галузей на певній території; визначено пріоритетні напрямки для місцевого економічного розвитку; визначено галузі, які мають бути пріоритетними в середньостроковій перспективі. В результаті запропоновано формування таких кластерів: гірничо-металургійний, будівельний, транспорту і логістики, машинобудівний, IT-бізнес. Структура кластерів відповідає «потрійній» та чотириланковій спіралі - «влада-бізнеснаука-суспільство (громадськість)». Як зазначено авторами, всі кластери міста $€$ комплементарними один одному 3 точки зору інвестиційно-інноваційної взаємодії, однак потребують посилення елементи інституціонального середовища на підставі створення відповідних норм, правил та регламентів 
щодо реалізації інсрраструктурних рішень, залучення державних та венчурних фондів, консалтингових та маркетингово-аналітичних компаній [13; 14]. Представлений досвід створення будівельного кластеру у м. Кривій Ріг із залученням підприємств з переробки доменних та сталеплавильних шлаків доцільно фрормалізувати та адаптувати для інших міст, які мають вирішувати подібні проблеми управління промисловими відходами.

Висновки. Процес управління промисловими відходами міста має особливості, які необхідно враховувати під час прийняття рішень, спрямованих на забезпечення його фрункціонування та розвитку. Ці особливості пов'язані 3 нормативно-правовим забезпеченням та взаємодією інститутів, можливостями фрінансування проектів розвитку, технологією надання послуг з переробки відходів (вторинних ресурсів). Заходи 3 управління промисловими відходами в частині переробки вторинних ресурсів пов'язані з інституціями, інноваціями та інвестиціями, повинні здійснюватися комплексно, оскільки при прийнятті та реалізації рішень з техніко-техноло- гічної модернізації (впровадження інновацій) потрібне фрінансове забезпечення (залучення та використання інвестицій), а також наявність відповідного інституційного середовища. Зазначене втілюється при формуванні кластеру з управління промисловими відходами на засадах «потрійної» та чотириланкової спіралі - «влада-бізнес-наука-суспільство (громадськість)». При цьому особливої уваги потребують питання створення інституційного середовища в рамках кластеру, пов'язаного із забезпеченням коопераційних зв'язків між учасниками, створення умов інвестиційної привабливості інноваційних проектів, що реалізуються учасниками кластеру, а також оцінка соціальної спрямованості інновацій щодо відновлення екосистемних фрункцій територій, які зайняті відвалами промислових відходів, зменшення шкідливого впливу на довкілля та комфортність умов життєдіяльності населення. Надалі доцільним $є$ дослідження питань організації участі суспільства (громадськості) в процесах управління промисловими відходами в рамках використання кластерного підходу.

\section{СПИСОК ВИКОРИСТАНИХ ДЖЕРЕЛ:}

1. Колодійчук І.А. Формування територіально збалансованих систем управління відходами: регіональний вимір : монографія. Львів : ДУ «Інститут регіональних досліджень імені М.І. Долішнього НАН України», 2020. 524 с.

2. Мініна О., Шадура-Никипорець Н. Дослідження регіональної специфріки процесів утворення і поводження з промисловими відходами. Галицький економічний вісник. 2020. № 3(64). С. 32-43.

3. Потапова Н.М. Еколого-економічні аспекти регіональної організації безвідходного виробництва в Україні. Вісник Приазовського державного технічного університету : зб. наук. праць / ДВНЗ «ПДТУ». Маріуполь, 2018. Вип. 36. С. 273-278.

4. Тімченко Р.О., Крішко Д.А., Тітунін Є.В. Рециклінг промислових відходів. Містобудування та територіальне планування. 2018. Вип. 67. С. 482-487.

5. Bartoleto A.P. Waste prevention policy and behaviour. New approaches to reducing waste generation and its environmental impacts. Routledge studies in waste management and policy. L.; N.Y. : Routledge, 2015. 202 p.

6. Marshall R.E., Farahbakhsh K. Systems approaches to integrated solid waste management in developing countries. Waste Management. 2013. Vol. 33. Iss. 4. P. 988-1003.

7. Никуличев Ю.В. Управление отходами. Опыт Европейского Союза. Москва : ИНИОН РАН, 2017. 55 с.

8. Лупин С.С. Классифрикация промышленных отходов как основа инфологической модели системы управления их переработкой и утилизацией. Известия Тульского государственного университета. Технические науки. 2018. Вып. 12. С. 300-307.

9. Білоус О. Держстат оприлюднив рейтинг областей за кількістю відходів. URL: https://www.rbc.ua/ukr/ news/gosstat-obnarodoval-reyting-oblastey-kolichestvu-1590147020.html

10. Титамир О. Засилля промислових відходів: чи вдасться Україні перейти до «циркулярної» економіки? Зеркало тижня. URL: https://zn.ua/ECOLOGY/zasilie-promyshlennykh-otkhodov-udastsja-li-ukraine-perejti-ktsirkuljarnoj-ekonomike.html

11. Решетняк О.І., Лободін Р.О. Кластери в інноваційній економіці: моделі потрійної, чотириланкової та п'ятиланкової спіралі. Вісник ОНУ імені І.І. Мечникова. 2020. Т. 25. Вип. 6(85). С. 69-73. URL: http://visnyk-onu.od.ua/ journal/2020_25_6/15.pdf

12. Попова А.О. Комерціалізація результатів інноваційної діяльності крізь призму моделі «Потрійна спіраль». Економічні інновації. 2015. Вип. 60. Книга II. С. 113-120. URL: http://dspace.nbuv.gov.ua/bitstream/ handle/123456789/98066/13-Popova. pdf?sequence=1 
13. Шевляков І., Газізулін І., Чередниченко Г., Муріна Г. Інвестиційні можливості: будівельний кластер м. Кривий Ріг. 2015. URL: https://ig.krmisto.gov.ua/dwn/citycard/investment_opportunities_ua.pdf

14. Борода М., Жолудь О. Кластерний аналіз економіки м. Кривий Ріг. 2014. URL: https://ig.krmisto.gov.ua/ dwn/citycard/cluster_analysis_ua.pdf

\section{REFERENCES:}

1. Kolodiichuk I.A. (2020) Formuvannia terytorialno zbalansovanykh system upravlinnia vidkhodamy: rehionalnyi vymir [Formation of geographically balanced waste management systems: a regional dimension]: monohrafiia [a monograph]. Lviv: DU «Instytut rehionalnykh doslidzhen imeni M.I. Dolishnoho NAN Ukrainy», 524 p. (in Ukrainian)

2. Minina O., Shadura-Nykyporets N. (2020) Doslidzhennia rehionalnoi spetsyfiky protsesiv utvorennia i povodzhennia z promyslovymy vidkhodamy [Research of regional specifics of industrial waste formation and management processes]. Halytskyi ekonomichny visnyk, no, 3(64), pp. 32-43.

3. Potapova N.M. (2018) Ekoloho-ekonomichni aspekty rehionalnoi orhanizatsii bezvidkhodnoho vyrobnytstva v Ukraini [Ecological and economic aspects of the regional organization of waste-free production in Ukraine]. Visnyk Pryazovskoho derzhavnoho tekhnichnoho universytetu: zb. nauk prats., vol. 36, pp. 273-278.

4. Timchenko R.O., Krishko D.A., Titunin Ye.V. (2018) Retsyklinh promyslovykh vidkhodiv [Industrial waste recycling]. Mistobuduvannia ta terytorialne planuvannia, vol. 67, pp. 482-487.

5. Bartoleto A.P. (2015) Waste prevention policy and behaviour. New approaches to reducing waste generation and its environmental impactsю. Routledge studies in waste management and policy. L.; N.Y.: Routledge, 202 p.

6. Marshall R.E., Farahbakhsh K. (2013) Systems approaches to integrated solid waste management in developing countries. Waste Management, vol. 33, iss. 4, pp. 988-1003.

7. Nikulichev Ju.V. (2017) Upravlenie othodami. Opyt Evropejskogo sojuza [Waste management. The experience of the European Union]. Moscow: INION RAN, 55 p.

8. Lupin S.S. (2018) Klassifikacija promyshlennyh othodov kak osnova infologicheskoj modeli sistemy upravlenija in pererabotkoj i utilizaciej [Classification of industrial waste as the basis of the infological model of the management system of their processing and disposal]. Izvestija Tul'skogo gosudarstvennogo universiteta. Tehnicheskie nauk, vol. 12, pp. 300-307.

9. Bilous O. Derzhstat opryliudnyv reitynh oblastei za kilkistiu vidkhodiv [The State Statistics Service published a rating of regions by the amount of waste]. Available at: https://www.rbc.ua/rus/news/gosstat-obnarodoval-reyting-oblastey-kolichestvu-1590147020.html

10. Tytamyr O. (2021) Zasyllia promyslovykh vidkhodiv: chy vdastsia Ukraini pereity do «tsyrkuliarnoi» ekonomiky? [Dominance of industrial waste: will Ukraine be able to move to a "circular" economy?]. Zerkalo nedeli. Available at: https://zn.ua/ECOLOGY/zasilie-promyshlennykh-otkhodov-udastsja-li-ukraine-perejti-k-tsirkuljarnojekonomike.html

11. Reshetniak O.I., Lobodin R.O. (2020) Klastery v innovatsiinii ekonomitsi: modeli potriinoi, chotyrylankovoi ta piatylankovoi spirali [Clusters in the innovation economy: models of triple, four-link and five-link spirals]. Visnyk ONU imeni I.I. Mechnykova, vol. 25, pp. 69-73. Available at: http://visnyk-onu.od.ua/journal/2020_25_6/15.pdf

12. Popova A.O. (2015) Komertsializatsiia rezultativ innovatsiinoi diialnosti kriz pryzmu modeli «Potriina spiral» [Commercialization of innovation results through the prism of the "Triple Spiral"Model]. Economic innovations, vol. 60, book II, pp. 113-120. Available at: http://dspace.nbuv.gov.ua/bitstream/handle/123456789/98066/13Popova.pdf?sequence=1

13. Shevliakov I., Hazizulin I., Cherednychenko H., Murina H. (2015) Investytsiini mozhlyvosti: budivelnyi klaster m. Kryvyi Rih [Investment opportunities: Kryvyi Rih construction cluster]. Available at: https://ig.krmisto.gov.ua/dwn/ citycard/investment_opportunities_ua.pdf

14. Boroda M., Žholud O. (2014) Klasternyi analiz ekonomiky m. Kryvyi Rih [Cluster analysis of the economy of Kryvyi Rih]. Available at: https://ig.krmisto.gov.ua/dwn/citycard/cluster_analysis_ua.pdf 